\title{
ANALISIS YURIDIS UNDANG - UNDANG NO. 16 TAHUN 2011 TENTANG BANTUAN HUKUM DALAM SISTEM PERADILAN PIDANA TERPADU SEBAGAI PERLINDUNGAN ATAS HAK ASASI MANUSIA
}

\author{
A. Hasyim Nawawie ${ }^{1}$, Johan ${ }^{2}$ \\ 1. Institut Agama Islam Negeri (IAIN) Tulungagung \\ 2. Polres Tulungagung
}

\begin{abstract}
ABSTRAK
Kedamaian dan keadilan dari masyarakat hanya bias dicapai apabila tatanan hokum telah terbukti mendatangkan keadilan dan dapat berfungsi dengan efektif. Perkembangan kehidupan masyarakat, sudah sangat kompleksitas sekali, seolah-olah menunjukan bahwa hukum dalam kehidupan manusia malahan sudah mencapai pada tingkat bahwa hokum sudah tidak lagi mampu untuk dipahami secara normal. Pada awalnya hokum dipercaya kehadirannya sebagai penjaga ketertiban(order) dimasyarakat, akan tetapi pelanggaran hukum dan ketertiban itu sendiri dimasyarakat makin tak terkalkulasi jumlahnya. Dengan adanya pemberian Bantuan Hukum yang dilakukan oleh Penasihat Hukum, maka suatu proses persidangan akan berjalan dengan seimbang(audietalterampartem), oleh karena para pihak dapat memberikan pendapatnya secara bebas dan proporsional, sehingga suatu peradilan yang adil dapat terwujud. Hak untuk memperoleh keadilan(accesstojustice) merupakan hak asasi yang dimiliki setiap warga negara. Negara sebagai pelindung dan pemerintah, wajib untuk memberikan perlindungan dan pembelaan kepada setiap warga Negara atas adanya perlakuan yang tidak adil yang dialami warga negara. Bahwa berdasarkan amanah dalam UUD1945, setiap warga memiliki persamaan kedudukan didalam hukum, dan berhak atas perlindungan hukum yang adil, serta persamaan perlakuan hukum, sehingga hak-hak warga Negara berdasarkan konstitusi wajib dijamin dan dilindungi oleh Negara dalam suatu peraturan perundang-undangan.

Rumusan masalah dalam penelian ini adalah : Bagaimana upaya pemberian bantuan hukum untuk mewujudkan perlindungan terhadap HAM (HakAsasiManusia) dalam Sistem Peradilan Pidana terpadu? Bagaimana masalah yang terdapat didalam pelaksanaan bantuan hukum berdasarkan Undang-Undang No.16 Tahun 2011 Tentang Bantuan Hukum dalam Sistem Peradilan Pidana Terpadu? Rumusan masalah tersebut dikaji secara mendalam dengan menggunakan metode pendekatan yuridis normative yang didasarkan pada hukum positif yang berlaku di Indonesia dengan klasifikasi dua sumber data yakni data primer dan data sekunder berupa undang-undang atau Peraturan lainnya yang masih ada hubungannya dengan masalah yang diteliti pada penulisan tesis sebagai pijakan teori serta buku-buku/bahan-bahan lain yang masih memiliki keterkaitan dengan judul penelitian ini sebagai bahan sumber sekundernya.

Adapun kesimpulan dari penelitian ini adalah : Pertama, Dapat disimpulkan bahwa upaya pemberian bantaun hukum yang tercantum dalam Undang-Undang No.16 Tahun terhadap terdakwa dalam sistem peradilan pidana terpadu sudah terintegrasi dengan PERMA Nomor 1 Tahun 2014 tetang Pedoman Pemberian Bantuan Hukum. Meski demikian hal ini belum dapat dikatakan efektif dan untuk mengukur seberapa efektif pemberian bantuan hukum itu sendiri setidaknya dapat ditentukan dari lima faktor diantaranya adalah faktor hukum itu sendiri yakni undang-undang dan peraturan yang terkait dalam hal ini sudah mengatur secara jelas, faktor dari aparat penegak hukum yakni advokat dalam menjalankan tugas serta kewajibannya diusahakan untuk selalu profesional, faktor sarana dan fasilitas yang meliputi LBH dengan fasilatas yang cukup memadahi.

Kedua, Adapun masalah yang terdapat dalam pelaksanaan bantuan hukum sesuai dengan Undang-Undang No. 16 Tahun 2011 Tentang Bantuan Hukum sangatlah kasustik sekali serta memerlukan penyelesaian secara nyata dengan tujuan manfaatnya dapat dirasakan oleh masyarakat miskin. Masalah yang dimaksudkan adalah tidak mengakomodir pemenuhan hak dari masyarakat miskin dan marginal guna mendapatkan bantuan hukum dan tidak pula mencantumkan sanksi bagi advokat ketika tidak mau memberikan bantuan hukum kepada masyarakat miskin.
\end{abstract}




\begin{abstract}
Peace and justice of the people can only be a chieve dif the legal order has proven to bring about justice and can function neffectively. The development of community life, has been very complex, as if showing that the law in buman life has even reached the level that the law is no longer able to be understood normally. In the beginning the law is believed to be the order keeper of the community, but the law lessness and the order itself insociety is increasing $y$ unpredictable.With the provision of Legal Aid by the Legal Counsel,a trial process will proceed equally (audietalterampartem), because the parties can give the ir opinions free ly and proportionally,so that afairtrial can be realized.The right to access is the basic righ tofe very citizen.The State as a protect or and the government, shall be obliged to provide protection and defense to every citizen for any unfair treatment experienced by the citizens. Where as based on the mandate of the 1945 Constitution, every citizen has equal status in the law, and is entitled to fair legal protection and equality of legal treatment, so that the right so citizens under the constitution must be guaranteed and protected by the stateina legislation

The formulation of the problem in this study is: How is the effort to provide legal aid to realize the protection of Human Right sinthe integrated Criminal Justice System? How the problems are contained in the implementation of legal aid based on Lawno.16 Year 2011 About Legal Aidin Integrated Criminal Justice System ? The formulation of the problem is studied in depth by using normative juridical approach based on positive law in Indonesia with classification of two data sources namely primary data and secondary data in the form of law or other regulation that still has to do with problem which is examined at writing thesis ast hetheoretical point of the theories and other books/material is that still have relevance to the title of this study as a source of secondary material.

The conclusions of this researchare: Firstly, it can be concluded that the effort of providing legal bantaun listed in Law No.16 Year against defend an tinintegrated criminal justice system bas been integrated with PERMA Number 1 Year 2014 neighboring Guidance of Legal Assistance. However, this can not be said to be effective and to measure how affectively the provision of legal aid itself can at least be determined from five factors such as the legal factor itself,the relevant laws and regulations in this case have been clearly set, the factors of the enforcement apparatus law that is advocate in carrying out their duties and obligations are endeavored to always be professional, facilities and facilities covering LBH with adequate facilities. Second, As for the problems contained in the implementation of legal aid in accordance with Lawno.16 Year 2011 About Legal Aid is very casseric as well and requires are also lution with the purpose of benefits can be felt by the poor. The intended problem is not to accommodate the fulfillment of the right sof the poor and marginal to obtain legal aid and not to includes anctions for advocates when they do not want to provide legal assistance to the poor.
\end{abstract}

\section{A. PENDAHULUAN}

Pada dasarnya masalah Bantuan Hukum sesungguhnya adalah masalah klasik, masyarakat miskin telah lama berharap akan adanya suatu proses peradilan yang adil yang dapat diakses oleh setiap warga negara, dengan adanya pengaturan mengenai pemberian Bantuan Hukum secara kongkret, yang dapat mengakomodir kepentingan hak - hak tersangka / terdakwa dalam proses pemeriksaan pidana. Tetapi aturan yang lahir hanyalah aturan yang lemah aturan dan penegakkannya sehingga tidak memiliki arti penting dalam mewujudkan pemenuhan hak asasi warga negara / tersangka untuk dapat memperoleh peradilan yang adil dan akses kepada keadilan; hal demikian layaknya peribahasa "de Bergen baren, een belachelijk muisje wordtgeboran" (gunung - gunung bersalin, maka lahirlah seekor tikus kecil yang lucu). ${ }^{1}$

Kasus yang muncul mungkin hanyalah sebagian kecil dari banyaknya pelanggaran hak asasi tersangka yang terjadi pada proses pemeriksaan perkara pidana, yang luput dari perhatian kita, demikian juga di dalam permasalahan hukum perdata di mana sering sekali terjadi kasus - kasus civil deprived Rights yang dilakukan oleh penguasa yang sewenang - wenang merampas hak - hak sipil warga negara. Hadirnya Lembaga Bantuan Hukum (LBH) dan aturan mengenai bantuan hukum ternyata belum banyak membantu pemenuhan hak asasi warga negara khususnya kepada tersangka, hal ini terbukti masih banyaknya kasus - kasus pidana yang diproses

1 V.B da Costa S.H. dalam Pemandangan Umum Fraksi Partai Demokrasi Indonesia mengenai RUU Hukum Acara Pidana, tanggal 8 November 1979. 
tanpa adanya bantuan dari penasihat hukum / Advokat, sehingga tidak jarang banyak masyarakat menjadi pasrah ketika hak - haknya ditindas dan diberikan putusan yang tidak adil oleh lembaga peradilan.

Peran Negara sebagai penguasa yang memberikan perlindungan kepada warga Negara selama ini selalu menutup mata dan cenderung membiarkan permasalahan itu tetap terjadi, sehingga akses keadilan dan akses pemenuhan hak konstitusionalitas warga Negara sering mengalami hambatan. Sehingga di manakah tanggung jawab Negara untuk memberikan keadilan dan perlindungan bagi warga negaranya.

Hak atas peradilan yang adil (fair trial rights) merupakan suatu hak untuk mendapatkan perlindungan dari pembatasan hak secara sewenang-wenang atau perampasan hak asasi dan kemerdekaan setiap manusia. Hak untuk mendapatkan peradilan yang adil (fair trial rights), berhak didapatkan oleh tersangka / tertuduh sejak di mulainya proses penanganan / pemeriksaan oleh pihak kepolisian atas tuduhan terhadap tersangka sampai dengan adanya putusan pengadilan yang telah berkekuatan hukum tetap (The rights to fair trial on criminal charge is considered to start running not "only upon the formal lodging of a charge but rather on the date on which states activities substantially affect the situation of the person concerned. 2

Hak untuk mendapatkan peradilan yang adil, adalah hak bagi setiap tersangka sebagai warga negara. Untuk dapat menuju terwujudnya suatu peradilan yang adil, maka kepada Tersangka / Terdakwa berhak untuk mendapatkan Bantuan Hukum, yang bertujuan untuk melindungi tersangka dari tindakan kesewenang-wenangan yang dilakukan oleh penegak hukum dalam proses hukum, berupa pelanggaran hak-hak tersangka, pemaksaan, dan kesewenang-wenangan. Bantuan Hukum merupakan suatu kewajiban yang wajib diberikan kepada setiap warga khususnya tersangka dalam perkara pidana pada setiap proses pemeriksaan, yang bertujuan untuk mewujudkan adanya suatu sistem peradilan pidana yang dijalankan dengan menghormati

${ }^{2}$ Manfred Nowak, U.N. Covenant on Civil and Political Rights, CCPR Commentary (N.P. Engel, Arlington: 1993) [hereinafter Nowak Commentary], at 244. hak-hak konstitusional dan asasi setiap warga negara dengan menjunjung tinggi asas praduga tak bersalah.

Dengan adanya pemberian Bantuan Hukum yang dilakukan oleh Penasihat Hukum, maka suatu proses persidangan akan berjalan dengan seimbang (audi et alteram partem), oleh karena para pihak dapat memberikan pendapatnya secara bebas dan proporsional, sehingga suatu peradilan yang adil dapat terwujud.

Negara Kesatuan Republik Indonesia adalah sebagai negara hukum (rechtsstaat) berdasarkan Pancasila dan Undang-undang Dasar Negara Republik Indonesia Tahun 19453, bertujuan mewujudkan tata kehidupan bangsa yang sejahtera, aman, tenteram, tertib dan berkeadilan.4 Prinsip negara hukum Indonesia menuntut adanya jaminan kesederajatan bagi setiap orang di hadapan hukum (equality before the law). Hal ini dapat tercermin dari ketentuan Pasal 28D ayat (1) Undang-undang Dasar Negara Republik Indonesia Tahun 1945 yang menyatakan:

Setiap orang berhak atas pengakuan, jaminan, perlindungan dan kepastian hukum yang adil serta perlakukan yang sama di hadapan hukum.5

Oleh karena itu Undang-Undang Dasar Negara Republik Indonesia Tahun 1945 juga menentukan bahwa setiap orang berhak atas pengakuan yang sama di depan hukum.6

Demikian dengan Pasal 27 ayat (1) Undang-Undang Dasar Negara Republik Indonesia Tahun 1945 yang menentukan bahwa setiap warga negara bersamaan kedudukannya di dalam hukum dan pemerintahan dan wajib menjunjung hukum dan pemerintahan itu dengan tidak ada kecualinya. Menurut Yuda Pandu maksud Pasal 27 Undang-undang Dasar Negara Republik Indonesia Tahun 1945 tersebut adalah setiap warga mempunyai hak dibela (accsess to legal counsel), sama diperlakukan di muka hukum

${ }^{3}$ RM. A.B. Kusuma, Sistem Pemerintaban "Pendiri Negara" Versus Sistem Presidensiel "Orde Reformasi". Badan Penerbit Fakultas Hukum Universitas Indonesia. Jakarta, 2011, hlm. 66.

${ }^{4}$ Agustin Teras Narang, Proses Pembahasan Undang-undang Nomor 18 Tahun 2003 tentang Advokat di Parlemen, Yayasan Pancur Siwah: Jakarta, 2003, hlm: 165.

5 Pasal 28D ayat (1) Undang-undang Dasar

Negara Republik Indonesia Tahun 1945

${ }^{6} \mathrm{Ibid}, \mathrm{hlm} .180$. 
(equality before the law) dan keadilan untuk semua (justice for all).7 Hak setiap orang atas pengakuan, jaminan, perlindungan dan kepastian hukum menimbulkan hak kepada warga negaranya untuk memperoleh bantuan hukum, baik di depan pengadilan maupun di luar pengadilan, hak untuk dibela adalah upaya setiap warga negara mendapat keadilan. 8

Pasal 24 Ayat (1) Undang-undang Dasar Negara Republik Indonesia Tahun 1945 menentukan bahwa kekuasaan kehakiman9 merupakan kekuasaan yang merdeka untuk menyelenggarakan peradilan guna menegakkan hukum dan keadilan. Oleh karena itu, selain pelaku kekuasaan kehakiman, yaitu Mahkamah Agung dan Mahkamah Konstitusi, badanbadan lain yang fungsinya berkaitan dengan kekuasaan kehakiman juga harus mendukung terlaksananya kekuasaan kehakiman yang merdeka. Salah satunya adalah profesi Advokat yang bebas, mandiri, dan bertanggungjawab, sebagaimana diatur dalam Undang-Undang Nomor 18 Tahun 2003 Tentang Advokat.

Berdasarkan latar belakang yang telah diuraikan diatas, maka penulis tertarik untuk membuat penulisan hukum yang berjudul : Analisis Yuridis Undang - Undang No. 16 Tahun 2011 Tentang Bantuan Hukum dalam Sistem Peradilan Pidana Terpadu Sebagai Perlindungan Atas Hak Asasi Manusia.

\section{Rumusan Masalah}

Adapun rumusan masalah dalam penelitian ini adalah:

1. Bagaimana upaya pemberian bantuan hukum untuk mewujudkan perlindungan

${ }^{7}$ Yuda Pandu. Klien dan Penasihat Hukum Dalam Perspektif Masa Kini. Perpustakaan Nasional. Jakarta. 2001. hlm. 15.

${ }^{8}$ Satya Arinanto. 2008. Hak. Asasi Manusia dalam Transisi Politik di Indonesia. Pusat Studi Hukum Tata Negara Fakultas Hukum Universitas Indonesia. Jakarta. hlm. 5. Konsepsi HAM muncul sejak era reformasi yang memperoleh landasan hukum signifikan semenjak diberlakukannya Kepress Nomor 129 Tahun 1998 tentang Rencana Aksi Nasional HAM tahun 1998-2003

Iriyanto. A. Baso Ence. Negara Hukum dan Hak Uji Konstitusionalitas Mabkamah Konstitusi (Telaah Terbadap Kewenangan Mabkamah Konstitusi). Alumni. Bandung, 2008. hlm. 120. Kekuasaan kehakiman dan peradilan dalam pandangan Moh. Mahfud MD adalah kekuasaan untuk memeriksa dan mengadili serta memberikan putusan atas perkara-perkara yang diserahkan kepadanya untuk menegakkan hukum dan keadilan berdasarkan perundang-undangan. terhadap HAM (Hak Asasi Manusia) dalam Sistem Peradilan Pidana terpadu?

2. Bagaimana masalah yang terdapat di dalam pelaksanaan bantuan hukum berdasarkan Undang - Undang No. 16 Tahun 2011 Tentang Bantuan Hukum dalam Sistem Peradilan Pidana Terpadu?

\section{Tujuan Penelitian}

Adapun tujuan dari penelitian ini adalah:

1. Untuk mengetahui dan mengkaji upaya pemberian bantuan hukum untuk mewujudkan perlindungan terhadap HAM (Hak Asasi Manusia) dalam Sistem Peradilan Pidana terpadu?

2. Untuk mengetahui dan mengkaji masalah apa yang terdapat di dalam pelaksanaan bantuan hukum berdasarkan Undang - Undang No. 16 Tahun 2011 Tentang Bantuan Hukum dalam Sistem Peradilan Pidana Terpadu?

\section{Manfaat Penelitian.}

Adapun manfaat yang bisa diambil dari hasil penelitian ini adalah sebagai berikut:

1. Manfaat Teoritis.

Hasil penelitian ini berguna sebagai sumbangan referensi bagi kalangan akademisi yang ingin memperdalam pengetahuan mengenai implementasi pemberian bantuan hukum dalam perkara pidana, khususnya di Kota Tulungagung.

2. Manfaat Praktis

a. Hasil penelitian ini dapat berguna bagi masyarakat luas, terutama bagi masyarakat miskin yang berperkara yang kurang mengetahui fungsi dan manfaat dari pemberian bantuan hukum CumaCuma sehingga mereka dapat memanfaatkan pemberian bantuan hukum guna mendapatkan jaminan perlindungan hukum terhadap hak asasi mereka apabila mereka berperkara.

b. Hasil penelitian ini dapat meningkatkan kesadaran dan motivasi bagi pemberi bantuan hukum untuk memberikan bantuan hukum cuma-cuma secara berkesinambungan sebagai bentuk pelayanan pada masyarakat.

c. Hasil penelitian ini dapat menjadi sumbangan pemikiran bagi Pemerintah Republik Indonesia guna melakukan revisi yang diperlukan terhadap peraturan perundang-undangan berkaitan dengan 
bantuan hukum sehingga dapat lebih mengakomodir kepentingan hukum masyarakat miskin.

\section{Metode Penelitian \\ Pendekatan Penelitian}

Metode pendekatan yang digunakan dalam penelitian ini adalah metode pendekatan yuridis normatif yang didasarkan pada hukum positif yang berlaku di Indonesia dengan cara meneliti bahan bacaan peraturan perundanganundangan dan pendapat para sarjana hukum yang terkemuka yang berkaitan dengan penelitian ini.

\section{Sumber Data}

Dalam penelitian ini, penulis menggunakan 3 sumber data, antara lain:

a) Bahan hukum primer.

Bahan hukum primer merupakan suatu bahan hukum yang mempunyai otoritas yang mengikat dan terdiri dari suatu norma atau kaidah dasar yang mana yang digunakan dalam penulisan ini, antara lain Undang-Undang Nomor 18 Tahun 2003 Tentang Advokat, Undang-Undang Nomor 16 Tahun 2011 Tentang Bantuan Hukum, dan peraturan perundangundangan lainnya yang berkaitan dengan bantuan hukum.

b) Bahan hukum sekunder.

Bahan hukum sekunder merupakan bahan hukum berupa publikasi hukum yang bukan bersifat dokumen resmi, meliputi buku teks, jurnal, pendapat para ahli hukum, dan sumber elektronik.

c) Bahan hukum tersier.

Merupakan bahan hukum penunjang yang pada dasarnya meliputi bahan-bahan yang memberikan petunjuk terhadap bahan hukum primer dan bahan hukum sekunder, seperti bibliografi hukum, direktori pengadilan, ensiklopedia hukum, indeks majalah hukum, kamus hukum, dan sebagainya.

\section{Teknik Pengumpulan Data}

Bahan hukum yang diperoleh, dikumpulkan, diinventarisasi dan diidentifikasi dari peraturan perundang-undangan dengan melakukan penelusuran melalui daftar petunjuk peraturan perundang-undangan. Bahan hukum yang telah diperoleh tersebut diolah sesuai kebutuhan penelitian untuk dipergunakan sesuai analisis pokok masalah penelitian

\section{Analisis Data}

Pengolahan, analisis dan konstruksi data dapat dilakukan dengan cara melakukan analisis terhadap kaidah hukum dan kemudian memasukkan pasal-pasal ke dalam kategorikategori atas pengertian dasar dari sistem hukum tersebut dengan cara sebagai berikut:

a) Menemukan konsep-konsep yang terkandung dalam bahan-bahan hukum (konseptualisasi) yang dilakukan dengan cara melakukan interpretasi terhadap bahan hukum tersebut;

b) Mengelompokkan konsep-konsep atau peraturan-peraturan yang sejenis, dalam hal ini yang berhubungan dengan bantuan hukum;

c) Menemukan hubungan antara berbagai peraturan atau kategori dan kemudian diolah;

d) Menjelaskan dan menguraikan hubungan antara berbagai kategori atau peraturan perundang-undangan kemudian dianalisis secara deskriptif kualitatif sehingga mengungkapkan hasil yang diharapkan serta kesimpulan atas permasalahan.

\section{B. PEMBAHASAN}

1. Pelaksanaan Bantuan Hukum Sesuai Undang-Undang No. 16 Tahun 2011 Tentang Bantuan Hukum.

Pelaksanaan Bantuan Hukum dalam UUBH merupakan Lembaga Bantuan Hukum atau Organisasi Kemasyarakatan selanjutnya disingkay dengan LBH dan Orkemas. Adapun pelaksanaan Bantuan Hukum dalam UndangUndang Mahkamah Agung dalam Pasal 42 yang disebut juga sebagai pembela. Undang-Undang kekuasaan Kehakiman menjelaskan adanya pengakuan pemebrian bantuan hukum sebagaimana yang termuat dalam ketentuan Pasal 38 ayat (2) huruf d undang-undang Peradilan Umum dengan ketentuan Pasal 68 C yang mana setiap Pengadilan Negeri dibentuk Pos Bantuan Hukum. Pemberian bantuan hukum menurut UUBH dilakukan oleh pelaksana bantuan hukum yang sudah memiliki badan hukum, terakreditasi, mempunyai kantor atau kesekretariatan tetap mempunyai pengurus serta program bantuan hukum sesuai dengan Pasal 8.

LBH berdasarkan Pasal 1 ayat (6) PP No. 83 Tahun 2008 tentang persyaratan dan tata cara pemberian bantuan hukum secara CumaCuma memiliki arti bahwa sebagai lembaga yang memberikan bantuan hukum terhadap para 
pencari keadilan tanpa menerima pembayaran honorarium. Para aktivis Pemberi Bantuan Hukum memasukkan tentang konsep bantuan hukum gender struktural sebagai respon atas ketidak adilan gender dikarenakan relasi kuasa yang timpang antar jenis kelamin. ${ }^{10}$

Adapun kegiatan bantuan hukum yang dikembangkan mencakup penyadaran serta pengorganisasian masyarakat, kampanye pers serta kerjasama dengan wartawan yang lain, mengusahakan untuk berpartisipasi terhadap mitra yang optimal dalam menangani perkara hukum dan keadilan, menggali serta membuat nyata dan menganalisis tentang kasus-kasus pelanggaran keadilan yang belum manifest, selain itu juga mengusahakan kerjasama dengan kekuatan yang ada serta tumbuh di masyarakat diantaranya tokoh informal baik itu indifidual ataupun secara kolektif. ${ }^{11}$

Orang yang melakukan pemberian terhadap bantuan hukum kepada kantor pelaksanaan bantuan hukum adalah advokat, paralegal mahasiswa dan dosen FH yang sudah memenuhi syarat. Advokat merupakan orang yang memiliki profesi untuk memberi jasa hukum baik itu dalam ataupun di luar pengadilan yang memenuhi persyaratan sesuai dengan ketentuan undang-undang advokat dalam naskah ini khasus klien yang tidak mampu atau orang miskin.

Dasar pertama pemberian bantuan hukum adalah Mukadimah Anggaran Dasar PERADIN, yang menjelaskan bawasanya hak setiap orang guna mendapatkan perlakuan serta perlindungan yang sama oleh undang-undang sesuai dengan asas rule of law dalam masyarakat yang merdeka. ${ }^{12}$

\section{Upaya Bantuan Hukum dalam Sistem Peradilan Pidana Terpadu}

Bantuan hukum pada dasarnya adalah sebuah program yang tidak hanya merupakan aksi kultural, akan tetapi juga aksi struktural yang diarahkan pada perubahan tetanan masyarakat yang tidak adil menuju dalam sistem

10 Kelompok Kerja Paralegal Indonesia, Kritisi Rancangan UUBH dari Aspek Paralegal dan Pemberdayaan Hukum (Legal Empowerment), KKPI, Jakarta, 2014, hlm. 15.

11 Benny K. Harman, Mulyana W. Kusumah, Hendardi, Paskah Irianto, Sigit Pranawa, dan Tedjabayu, LBH Memberdayakan Rakyat, Membangun Demokrasi, YLBHI, Jakarta, 1995, hlm. 7.

12 Badan Kontak Profesi Hukum Lampung, Penegakan Hukum dalam Mensukseskan Pembangunan, Alumni, Bandung, 1977, hlm. 33. masyarakat yang lebih mampu untuk memberikan nafas yang nyaman bagi golongan mayoritas. Oleh sebab itu, bantuan hukum bukanlah masalah yang sedehana. Ia adalah tindakan pembebasan masyarakat dari belenggu struktur politik ekonomi dan sosial yang sarat dengan penindasan.

Konseptualisasi tentang bantuan hukum tidak untuk menghindarkan diri dari tujuan guna menata kembali masyarakat dari kepincangan struktural yang tajam dengan menciptakan pusat-pusat kekuatan serta melaksanakan partisipasi dari bawah. Hal ini cukup penting mengingat bahwa disini adalah supaya rakyat miskin mayoritas yang berada di pinggiran harus dikembalikan hak-hak dasar mereka akan sumber-sumber daya politik, ekonomi, informasi,teknologi dan informasi agar mereka dapat menentukan masyarakat bagaimana yang mereka kehendaki. ${ }^{13}$

Pemberi bantuan hukum merupakan lembaga bantuan hukum atau organisasi kemasyarakatan yang memberi layanan bantuan hukum sesuai dengan UU ini (Pasal 1 angka 3 UU No. 6 Tahun 2011). Kendati LBH atau organisasi kemasyarakatan diberi kepercayaan untuk memberi bantuan hukum, akan tetapi dalam praktiknya dilakukan oleh advokat berlisensi (sesuai dengan ketentuan undangundang).

Adapun menurut Soerjono Soekanto, masalah pokok dari penegakan hukum pada dasarnya terletak pada faktor-faktor yang mungkin mempengaruhinya, yakni faktor hukumanya sendiri, faktor penegak hukum, faktor masyarakat dan faktor kebudayaan. ${ }^{14}$

Sementara faktor-faktor pelaksanaan bantuan hukum bagi orang atau kelompok orang miskin, apabila dikaji lebih dalam dari teori sistem hukum dari Lawrence M. Friedman dan konsep faktor-faktor yang mempengaruhi terhadapnya, hukum-hukum dari Soerjono Soekanto, dengan mengacu pada hasil penelitian yang didapat, dapat diklasifikasikan serta dibedakan menjadi 3 faktor yakni, faktor substansi hukum, struktural hukum dan budaya hukum.

Kelima faktor untuk mengukur efektivitas pemberian bantuan hukum terhadap terdakwa tidak mampu oleh Advokat seperti teori yang disebutkan Soerjono Soekanto, dapat

\footnotetext{
${ }^{13}$ Frans Hendra Winarta, Op.cit., hlm. 22

14 Soerjono Soekanto, Op cit, hlm: 15
} 
kita simpulkan bahwa sebenarnya hukum itu sendiri yaitu undang - undang, Peraturan Pemerintah, SEMA, Kode Etik Profesi, semuanya telah mengatur dan menyebutkan secara jelas segala hal yang terkait dengan hal tersebut.

Penegak hukum yakni advokat kendati ada saja yang belum terketuk hati nuraninya dalam membela masyarakat kurang mampu namun sebagain dari mereka juga sudah berupaya menjalankan tugas sebaik-baiknya sesuai kewajiban profesi serta menganggap ini sebagai bagian dari ibadah karena menolong orang yang sedang kesulitan tanpa sebuah pamrih.

Mereka siap membantu masyarakat tidak mampu yang sedang berhadapan dengan hukum tanpa mengharapkan imbalan namun harus tetap profesional tidak membeda - bedakan dengan klien lainnya.

Faktor sarana dan fasilitasnya juga sudah cukup mendukung. Fasilitas yang ada di LBH Kopri dan PN Bandung, sudah tergolong layak meskipun belum sepenuhnya masyarakat yang jauh tinggal di pelosok desa dapat mengakses kantor ini. Sumber daya manusia yang berkualitas yaitu Advokat yang sudah berpengalaman menangani berbagai perkara.

Dalam hal ini, yang membuat efektivitas pemberian bantuan hukum terhadap terdakwa tidak mampu tidak dapat berjalan optimal dan efektif adalah faktor dari masyarakatnya. Masyarakat tidak dengan mudahnya datang ke LBH di PN Bandung untuk meminta bantuan saat mereka bermasalah dengan hukum. Ini dikarenakan tingakat kesadaran hukum mereka yang masih kurang dan mereka masih ragu dengan kinerja Advokat yang mereka pahami selama ini bahwa Advokat adalah profesi yang identik dengan uang. Mereka belum bisa memahami sepenuhnya hakikat dari didirikannya LBH untuk membantu mereka dalam memperoleh keadilan. Ini berdampak pada faktor kebudayaan yang berkembang ditengah masyarakat yang akhrinya salah.

Menjadi tugas seorang advokat supaya dapat meluruskan budaya masyarakat yang salah, mereka pelru terus untuk meyakinkan masyarakat bahwa advokat sepenuhnya mampu membantu mereka dalam menyelesaikan masalah hukum yang tengah dihadapi tanpa meminta untuk sebuah imbalan semata.
Menurut Satjipto Rahardjo ${ }^{15}$ bahwa, sebagai suatu proses, penegakan hukum pada hakikatnya merupakan variabel yang mempunyai korelasi dan interdependensi dengan faktor-faktor yang lain. Ada beberapa faktor terkait yang menentukan proses penegakan hukum sebagaimana diungkapkan oleh Lawrence M. Friedman, yaitu komponen substansi, struktur dan kultural.

Beberapa komponen tersebut termasuk ruang lingkup bekerjanya hukum sebagai suatu sistem. Faktor - faktor ini akan sangat menentukan proses penegakan hukum dan kegagalan pada salah satu komponen akan berimbas pada faktor lainnya.

Faktor substansi, struktur, dan kultural akan sangat menentukan proses penegakan hukum atau proses pelaksanaan bantuan hukum bagi orang atau kelompok orang miskin dalam perkara pidana. Pembahasan faktor - faktor penghambat pelaksanaan bantuan hukum bagi orang atau kelompok orang miskin dalam perkara pidana, sangat terkait dengan teori sistem hukum dari Lawrence M. Friedman dan konsep faktor-faktor yang mempengaruhi penegakan hukum hukum dari Soerjono Soekanto.

Sistem hukum yang terdiri dari sub sistem hukum yang itu meliputi tentang substansi hukum, struktur hukum dan budaya hukum sebagaimana yang telah diuraikan dalam landasan teoritis mengenai teori sistem hukum dari Lawrence M. Friedman. Ketiga sub sistem yang dimaksud inilah yang sangat menentukan apakah suatu sistem dapat berjalan atau tidak, dan ketiga sub sistem inilah yang juga menentukan bantuan hukum bagi orang atau kelompok orang miskin dalam perkara pidana, dapat berjalan dengan baik atau tidak.

\section{Problematika Pemberian Bantuan Hukum dalam Undang - Undang No. 16 Tahun 2011}

Masalah yang mencuat ke permukaan, sering sekali dihadapi oleh orang miskin yakni akses terhadap keadilan, terlebih bagi mereka yang sedang berhadapan atau bermasalah dengan hukum. Inilah salah satu dari dimensi kemiskinan dari sisi yang lain yang mana akses terhadap keadilan pun merka sangat minim, lalu

15 Satjipto Rahardjo, Penegakan Hukum; Suatu Tinjauan Sosiologis, Genta Publishing Yogyakarta, 2009, hlm: viii. 
bagaimana mereka bisa mendapatkan perlakuan yang adil dalam peradilan. Meski negara dalam persoalan hukum telah menetapkan dueprocess of law (proses hukum yang adil), akan tetapi praktiknya tidaklah sesederhana yang ada dalam asas hukum tersebut. Masih ada pihak-pihak yang menginginkan agar proses hukum itu tidak berjalan sebagaimana mestinya, baik dari aparat penegak hukum (polisi, jaksa, hakim, petugas lembaga pemasyarakatan, dan advokat) maupun dari orang miskin tersebut.

Menolong orang lain dari sisi kemanusiaan memang hal yang baik, akan tetapi menyelesaikan persoalan hukum bukanlah sesuatu yang gratis, sehingga banyak pihak yang tidak untuk membantu orang lain apabila tidak ada keuntungan ekonomis yang diperolehnya. Apa yang diperoleh dari sisi ekonomi dengan menolong orang miskin. Inilah problema yang dihadapi oleh kaum miskin untuk mendapatkan access to justice. Advokat meski memiliki asas pro bono publico, serta kewajiban yang dibebankan oleh undang-undang untuk menolong kaum miskin, akan tetapi dalam praktiknya tidak mudah untuk mewujudkannya, apalagi telah terjadi pergeseran makna profesi advokat dari officium nobile ke komersialisasi. Negara mencoba mengatasi dengan mengeluarkan undang undang tentang bantuan hukum, yang berupa penyediaan dana yang dapat diakses oleh advokat yang telah memberikan bantuan hukum bagi rakyat miskin.

Keluarnya undang-undang No. 16 Tahun 2011, sekaligus menunjukkan bahwa memperoleh bantuan hukum bagi rakyat memang tidak gratis meski biaya itu ditanggung oleh Negara. Bantuan hukum cuma - cuma akhirnya hanya sekadar mitos belaka. Persoalan tidak berhenti pada hal tersebut, karena untuk mencairkan dana bantuan hukum bukanlah persoalan yang mudah juga. Ada prosedur dan birokrasi yang tidak dipahami oleh para advokat untuk mengakses dana itu. Tesis ini hendak membahas mengenai persoalan access to justice bagi rakyat miskin yang berkaitan dengan persoalan kepekaan sosial advokat dan kesulitan bagi advokat dalam mengakses dana bantuan hukum.

Artinya, terdapat beberapa masalah yang medasar terhadap di berikannya bantuan hukum oleh Negara kepada kaum miskin atau kaum marjinal, masalah tersebut, yakni sebagai berikut:

\section{Tidak Mengakomodir Bantuan Hukum Terhadap Hak Masyarakat Miskin dan kaum Marginal.}

Sepanjang sejarah perjalanan Republik Indonesia, belum ada satupun produk hukum setingkat UU (lex specialis) yang khusus mengatur mengenai bantuan hukum cuma - cuma, namun setelah 40 tahun diperjuangkan, akhirnya Dewan Perwakilan Rakyat (DPR) mengesahkan UU No. 16 Tahun 2011 Tentang Bantuan Hukum. Dalam UU ini pertama kali negara secara tegas menyatakan akan memberikan dukungan dalam penyelenggaraan dan pendanaan terhadap pemberian bantuan hukum terhadap masyarakat miskin dan marginal. Undang-Undang ini dianggap sebagai niatan baik pemerintah untuk menjamin hak warganya, sehingga persamaan warga negara di hadapan hukum bukan hanya menjadi jargon-jargon belaka.

Walupun sudah disahkan, dan diberlakukan, selalu saja didapati ketidaksingkronan antara harapan masyarakat miskin dan marginal dengan kenyataan yang ada ketika mereka hendak menggunakan aturan UU tersebut untuk mengakses bantuan hukum.

Selain hal tersebut, sejarah ambivalensi agaknya terus berlanjut di mana banyaknya produk UU tak pernah memberikan jaminan dalam praktek penegakannya. Sehingga penegakan hukum bukanlah hadiah namun berkah dari perjuangan bersama yang berkelanjutan. Walaupun begitu kehadiran UU No. 16 Tahun 2011 ini kian meyakinkan kita bahwa bantuan hukum adalah bagian dari Hak Konstitusi setiap warga negara tanpa terkecuali.

Dengan tingginya harapan yang digantungkan kepada UU 16 Tahun 2011, apakah kesalahan - kesalahan pengaturan di masa lalu masih terulang lagi. Beberapa jaringan masyarakat sipil (civil society) yang mendorong dan memberi masukan terhadap Rancangan Undang-Undang (RUU) Bantuan Hukum antara lain: Jaringan Koalisi Masyarakat Sipil untuk Bantuan Hukum (KuBAH) ${ }^{16}$, Pos Bantuan Hukum PERADI, Jaringan Paralegal Indonesia (JPI) dan jaringan LKBH Kampus. ${ }^{17}$

16 mengenai RUU Bantuan dapat dibaca di www.bantuanhukum.or.id/index.php/id/berita/press-

release/494-ruu-bantuan-hukum, diakses pada 24 Maret 2018.

${ }^{17}$ Indonesian Legal Resource Center (ILRC) dan Forum Solidaritas LKBH Kampus didukung oleh Open Society Institute menyuusn suatu position paper untuk 
Ada kekhawatiran saat itu, UU Nomor 16 Tahun 2011 justru tidak mengakomodir pelayanan bantuan hukum yang telah dilakukan oleh berbagai lembaga dan justru menyulitkan masyarakat ketika ingin mendapatkan akses terhadap bantuan hukum. Berbagai elemen masyarakat yang terlibat saat itu menginginkan agar UU Bantua Hukum ini benar-benar telah memberikan jaminan akses terhadap keadilan melalui bantuan hukum dan mengakomodasi entitas-entitas yang telah terbukti melaksanakan kegiatan bantuan hukum kepada masyarakat.

\section{Tidak Terdapat Klausula Sanksi Bagi Advokat yang Tidak Memberikan Bantuan Hukum \\ Undang-undang Advokat mendefinisikan} Bantuan Hukum sebagai jasa bukum yang diberikan oleh Advokat secara cuma - cuma kepada klien yang tidak mampu. Pemberian bantuan hukum tersebut merupakan kewajiban bagi Advokat, yaitu berdasarkan Pasal 22 ayat (1): Advokat wajib memberikan bantuan bukum secara cuma-cuma kepada pencari keadilan yang tidak mampuNamun kewajiban memberikan bantuan hukum oleh Advokat di dalam Undang undang Advokat tidak dijelaskan lebih lanjut ruang lingkupnya dan proporsinya.

Undang - Undang Advokat dan PP No.83 Tahun 2008 tidak memuat ketentuan sanksi yang tujuannya untuk menjamin Advokat melaksanakan kewajiban pemberian bantuan hukum secara cuma - cuma kepada pencari keadilan yang tidak mampu. Pemberian bantuan hukum cuma-cuma dari Advokat dalam undang-undang adalah penegasan saja dari bentuk tanggung jawab etik profesi advokat. Kalau pun Advokat tidak melaksanakan kewajibannya memberikan bantuan hukum cuma-cuma, Advokat tersebut hanya dapat diberikan sanksi administratif sebagaimana yang diatur dalam Pasal 14 Ayat (2) PP No.83 Tahun 2008, yaitu: ${ }^{18}$

(1)teguran lisan; (2) teguran tertulis; (3) pemberhentian sementara dari profesinya selama 3 (tiga) sampai dengan 12 (dua belas) bulan berturut-turut; atau (4). pemberbentian tetap dari profesinya.

memberi masukan terhadap RUU Nomor 16 Tahun 2011 dengan judul "Menjamin Hak Atas Bantuan Hukum Bagi Masyarakat Miskin dan Marginal: Position Paper RUU Nomor 16 Tabun 2011 dan Peran LKBH Kampus' pada Agustus 2010

18 Pasal 14 Ayat (2) PP No.83 Tahun 2008.
Selain sanksi administratif tersebut, sanksi lain hanya bisa dilakukan organisasi Advokat berdasarkan Kode Etik Advokat.

Selain itu, sanksi administratif tersebut hanya bisa dilakukan organisasi advokat berdasarkan Kode Etik Advokat. Pasal 4 Huruf f Kode Etik Advokat menyebutkan, Advokat dalam mengurus perkara cuma-cuma harus memberikan perhatian yang sama seperti terhadap perkara untuk mana ia menerima uang jasa. Dengan adanya katanya "harus" maka ukuran normanya adalah moral. Artinya memberikan bantuan Cuma-Cuma bukanlah kewajiban setiap advokat melainkan tuntutan moral dari setiap advokat.

Maka, dengan demikian Advokat tidak bisa diberikan sanksi lantaran tidak melaksanakan "keharusan" tersebut, kecuali ketika Advokat melaksanakan keharusan tersebut terbukti meminta uang jasa kepada klien yang tidak mampu. Kalaupun terbukti, sifat sanksinya adalah administratif dan pemerintah tidak bisa melakukan intervensi pada setiap putusan sanksi administratif yang dilakukan oleh organisasi advokat.

Sifat dari moral bantuan hukum CumaCuma tersebut diperkuat dengan Pasal 3 huruf A Kode Etik Advokat, bahwa Advokat dapat menolak untuk memberi nasihat dan bantuan hukum kepada setiap orang yang memerlukan jasa dan atau bantuan hukum dengan pertimbangan oleh karena tidak sesuai dengan keahliannya dan bertentangan dengan hati nuraninya, tetapi tidak dapat menolak dengan alasan karena perbedaan agama, kepercayaan, suku, keturunan, jenis kelamin, keyakinan politik dan kedudukan sosialnya.

Bisa saja seorang advokat menolak memberikan bantuan hukum kepada pencari keadilan yang tidak mampu dengan pertimbangan "bertentangan dengan hati nuraninya" atau "tidak sesuai dengan keahliannya". Misalnya, ada orang yang tidak mampu ingin mengajukan gugatan malpraktek. Orang tersebut datang kepada advokat dan advokat tidak sanggup memberikan bantuan hukum Cuma-Cuma lantaran banyak perkara yang harus ditangani atau tidak sesuai dengan keahliannya. Akhirnya orang yang tidak mampu itu datang ke Posbankum Pengadilan, ternyata Advokat Piket tidak ada di Posbankum.

Contoh kasus tersebut sudah sering banyak terjadi, sehingga dalam Penjelasan UU No.16 Tahun 2011 mengatakan, Hak atas 
Bantuan Hukum telah diterima secara universal yang dijamin dalam Kovenan Internasional tentang Hak-Hak Sipil dan Politik (International Covenant on Civil and Political Rights (ICCPR)).

Pasal 16 dan Pasal 26 ICCPR menjamin semua orang berhak memperoleh perlindungan hukum serta harus dihindarkan dari segala bentuk diskriminasi. Sedangkan Pasal 14 ayat (3) ICCPR, memberikan syarat terkait Bantuan Hukum yaitu:

a. Kepentingan - kepentingan keadilan,

b. Tidak mampu membayar Advokat.

Selama ini, pemberian Bantuan Hukum yang dilakukan belum banyak menyentuh orang atau kelompok orang miskin, sehingga mereka kesulitan untuk mengakses keadilan karena terhambat oleh ketidakmampuan mereka untuk mewujudkan hak-hak konstitusional mereka. Pengaturan mengenai pemberian Bantuan Hukum dalam Undang-Undang ini merupakan jaminan terhadap hak-hak konstitusional orang atau kelompok orang miskin.

Atas dasar ketentuan Kovenan Internasional tentang Hak-Hak Sipil dan Politik dan situasi bantuan hukum yang terjadi saat ini, dibuatlah UU No.16 Tahun 2011. Dalam UU No.16 Tahun 2011, Pemberi Bantuan Hukum adalah lembaga bantuan hukum atau organisasi kemasyarakatan yang memberi layanan Bantuan Hukum berdasarkan Undang-Undang ini.

Syarat-syarat lembaga bantuan hukum atau organisasi kemasyarakatan yang memberi layanan Bantuan Hukum yang dapat disebut sebagai Pemberi Bantuan hukum adalah:

a. Berbadan hukum;

b. Terakreditasi berdasarkan UndangUndang ini;

c. Memiliki kantor atau sekretariat yang tetap;

d. Memiliki pengurus; dan

e. Memiliki program Bantuan Hukum.

Lembaga bantuan hukum atau organisasi kemasyarakatan yang belum memenuhi persyaratan tersebut di atas tetap dapat memberikan Bantuan Hukum selama Lembaga bantuan hukum atau organisasi kemasyarakatan tersebut mempunyai advokat berdasarkan UU Advokat.

Kode etik advokat menegaskan bahwa kepribadian advokat antara lain: ${ }^{19}$

${ }^{19}$ Kode etik keprofesian advokat.
"Advokat dapat menolak untuk memberi nasihat dan bantuan bukum kepada setiap orang yang memerlukan jasa dan atau bantuan bukum dengan pertimbangan oleh karena tidak sesuai dengan keabliannya dan bertentangan dengan hati nuraninya, tetapi tidak dapat menolak dengan alasan karena perbedaan agama, kepercayaan, suku, keturunan, jenis kelamin, keyakinan politik dan kedudukan sosialnya."

Sementara itu, dalam Peraturan Internal Perhimpunan Advokat Indonesia (PERADI) No. 1 Tahun 2010 tentang Petunjuk Pelaksanaan Pemberian Bantuan Hukum Secara cuma-cuma diatur bahwa pengacara wajib memberikan bantuan hukum cuma-cuma, hanya saja dalam aturan berikutnya mereka hanya dianjurkan untuk memberikan bantuan hukum 50 jam dalam kurun waktu satu tahun, jika tidak dilaksanakan tidak terdapat sanksi memaksa dari organisasi advokat. Akibatnya, realisasi praktek pro bono advokat tidak berjalan.

Kurangnya kadar dedikasi para pengacara sukses di Indonesia untuk memberikan bantuan hukum probono. Seolah-olah muncul pemikiran bahwa perkara probono lebih pantas ditangani LBH di bawah naungan Yayasan Lembaga Bantuan Hukum Indonesia (YLBHI). Padahal memberikan bantuan hukum kepada pencari keadilan miskin adalah kewajiban setiap advokat sebagaimana diatur dalam UU Advocat, Kode Etik maupun aturan Internal organisasi advokat.

Sementara itu, jika merujuk pada jaminan pemberian bantuan hukum kepada masyarakat dalam UU Kekuasaan Kehakiman memiliki keterbatasan. UU kekuasaan kehakiman hanya menjamin hak atas bantuan hukum bagi masyarakat yang tidak mampu membayar jasa advokat karena persoalan kemiskinan, namun tidak menjamin hak atas bantuan hukum bagi masyarakat yang termarginalkan.

Selain itu, pemenuhan hak atas bantuan hukum melalui Pos Bantuan Hukum di Pengadilan sebatas proses hukum di Pengadilan sementara hak atas bantuan hukum sendiri ada dan dijamin undang-undang sejak proses penyelidikan di kepolisian.

Persoalannya kemudian adalah tidak adanya jaminan kualitas bantuan hukum yang diberikan, mengingat bantuan hukum diberikan baru saat di pengadilan, padahal penanganan sebuah kasus hukum membutuhkan keterlibatan seorang advokat sejak awal untuk 
mempersiapkan penanganan perkara dan pembelaan dengan baik. Konsep pemberian bantuan hukum seperti ini seolah menunjukkan bahwa hukum selalu netral dan berfungsi secara ideal.

Padahal faktanya tidak demikian. Belum lagi mengenai keterbatasan anggaran pengadilan untuk menyediakan dana bantuan hukum juga ketersediaan pos bantuan hukum yang ada di pengadilan, belum disemua pengadilan ada pos bantuan hukum. Ini mengakibatkan akses bantuan hukum tidak memiliki jaminan kepastian dan keberlanjutan.

\section{KESIMPULAN}

Adapun yang menjadi kesimpulan dari penelitian ini adalah sebagai berikut:

1. Dapat disimpulkan bahwa upaya pemberian bantaun hukum yang tercantum dalam Undang-Undang No 16 Tahun terhadap terdakwa dalam sistem peradilan pidana terpadu sudah terintegrasi dengan PERMA Nomor 1 Tahun 2014 tetang Pedoman Pemberian Bantuan Hukum. Meski demikian hal ini belum dapat dikatakan efektif dan untuk mengukur seberapa afektif pemberian bantuan hukum itu sendiri setidaknya dapat ditentukan dari lima faktor diantaranya adalah faktor hukum itu sendiri yakni undang-undang dan peraturan yang terkait dalam hal ini sudah mengatur secara jelas, faktor dari aparat penegak hukum yakni advokat dalam menjalankan tugas serta kewajibannya diusahakan untuk selalu profesional, faktor sarana dan fasilitas yang meliputi LBH dengan fasilatas yang cukup memadahi.

2. Adapun masalah yang terdapat dalam pelaksanaan bantuan hukum sesuai dengan Undang-Undang No. 16 Tahun 2011 Tentang Bantuan Hukum sangatlah kasustik sekali serta memerlukan penyelesaian secara nyata dengan tujuan manfaatnya dapat dirasakan oleh masyarakat miskin. Masalah yang dimaksudkan adalah tidak mengakomodir pemenuhan hak dari masyarakat miskin dan marginal guna mendapatkan bantuan hukum dan tidak pula mencantumkan sanksi bagi advokat ketika tidak mau memberikan bantuan hukum kepada masyarakat miskin.

\section{DAFTAR PUSTAKA}

Abraham S Blumberg, The Practice of Law as Confidence Game: Organizational Cooptation of a Profession. University of New York, 1967

Abdul Rachman, Aspek-Aspek Bantuan Hukum di Indonesia. Cendana Press: Jakarta, 1983.

Abdul Latif, Fungsi Mabkamah Konstitusi Dalam Upaya Mewnjudkan Negara Hukum Demokrasi, Total Media, Yogyakarta, 2007.

Adam Podgorecki \& Christopher J. Whelan, Pendekatan Sosiologi Terhadap Hukum, PT. Bina Aksara: Jakarta, 1987.

Adnan Buyung Nasution, Bantuan Hukum di Indonesia, LP3S: Jakarta, 1980.

Agustin Teras Narang, Proses Pembahasan Undang-undang Nomor 18 Tahun 2003 tentang Advokat di Parlemen. Yayasan Pancur Siwah: Jakarta, 2003.

Algra N. E. dan H.C.J.G. Jansen, Rechtsingang Een Orientasi in Het Recht, H.D. Tjeenk Willink bv, Groningen, 1974.

Anthon F. Susanto, Mitos Hukum di Tengah Percepatan Perubaban, Dalam Wajah Hukum di Era Reformasi, Kumpulan Karya Ilmiah Menyambut 70 Tahun Prof. Dr. Satjipto Rahardjo., SH., PT. Citra Aditya Bakti: Bandung, 2000.

Konstruksi Sosuial Tentang Penyimpangan, Mekanisme Kontrol dan Akuntabilitas Peradilan Pidana, PT. Refika Aditama : Bandungm, 2004.

Aristoteles, Politica, The Modern Library, New York, 1943.

Asfinawati, Prolog: Bantuan Hukum Cuma-Cuma dan Komersialisasi, dalam Lembaga Bantuan Hukum Jakarta, Bantuan Hukum Akses Masyarakat Miskin dan Marjinal terhadap Keadilan, Jkarta: LBH Jakarta, 2007.

Bambang Priyambodo, Politik. Hukum Peradilan Tata Usaha Negara. MP Press: Bandung, 1997.

Bambang Sunggono \& Aries Harianto, Bantuan Hukum dan Hak Asasi Manusia, Mandar Maju: Bandung, 2001.

Bagir Manan, Perkembangan Pemikiran Dan Pengaturan Hak Asasi Manusia Di Indonesia, Alumni, Bandung, 2006. ----Mewriudkan Kedaulatan Rakyat Melalui Pemiliban Umum, dalam Bagir 
Manan (Ed), Kedaulatan Rakyat, Hak Asasi Manusia dan Negara Hukum, Gaya Media Pratama, Jakarta, 1996. --,Mewujudkan Kedaulatan Rakyat Melalui Pemiliban Umum, dalam Bagir Manan (Ed), Kedaulatan Rakyat, Hak Asasi Manusia dan Negara Hukum, Gaya Media Pratama, Jakarta, 1996.

Darji Darmodhardjo, Pokok-Pokok Filsafat Hukum, Apa dan Bagaimana Filsafat Hukum Indonesia. Gramedia Pustaka Utama: Jakarta, 2008.

Dudu Duswara Machmudin, Pengantar Ilmu Hukum: Sebuah Sketsa, PT. Refika Aditama: Bandung, 2000.

Dicey, AV, An Introduction to Study of The Law of The Constitution, Macmillian, London, 2001.

Edi Suharto, Pekerjaan Sosial di Dunia Industri. Refika Aditama: Bandung, 2007.

Enschede , Ch.J., Beginselen Van Strafrecht, Kluwer Deventer, 2002.

Eko Prasetyo, Orang Miskin dilarang Sakit, Resirt Books: Yogyakarta, 2005.

Hamid S. Attamimi, A, Teori PerundangUndangan Indonesia, Makalah pada Pidato Upacara Pengukuhan Jabatan Guru Besar Tetap di Fakultas Hukum UI Jakarta, 25 April 1992.

Henry J. Abraham, Freedom and The Court, second edition, Oxford University Press, USA, 1972.

Hestu Cipto Handoyo,B, Hukum Tata Negara Indonesia. Universitas Atma Jaya: Yogyakarta, 2009.

Hebert L Packer, The Limits of the Criminal Sanction, Oxford University Press, 1968.

Iswara, Pengantar Ilmu Politik, Dhirwantara, Bandung, 1967.

Justice for The Poor - The World Bank, Menciptakan Peluang Keadilan, Jakarta: The World Bank, 2005.

John Rawls, Teori Keadilan, Pustaka Pelajar : Yogyakarta, 2009.

Kaelan, Pendidikan Pancasila, Paradigma : Yogyakarta, 2000.

Lawrence M Friedman \& Stewart Maculay, Law and Behavioral Science, Indianapolis : The Boobs Merrill Company Inc, 1969.

Luhut M.P. Pangaribuan, Advokad dan Contempt of Court Suatu Proses di Dewan
Kehormatan Profesi, Penerbit Djambatan : Jakarta, 1996.

Maragaret M. Poloma, Sosiologi Kontemporer, PT. RajaGrafindo Persada: Jakarta, 2007.

Yahya Harahap, M, Beberapa Tinjauan Mengenai Sistem Peradilan dan Penyelesaian Sengketa, Bandung: Citra Aditya Bakti, 1997.

Mulholand, RD, Introduction to The New Zaeland Legal System, Wellington Butterworths, New Zaeland, 1995.

Muladi, Kapita Selekta Sistem Peradilan Pidana. Semarang: Badan Penerbit Universitas Diponegoro, 1995.

Michael Cavadino dan James Dignan, The Penal Sistem An Introduction, 1997, SAGE Publication Ltd.

Solly Lubis, M, Serba-serbi Politik dan Hukum, Mandar Maju: Bandung, 1989.

Negara Hukum, Ensiklopedia Indonesia (N-Z), Ikhtiar Baru -van Hoeven, Jakarta, 2002

Oemar Seno Adji, KUHAP Sekarang, Erlangga : Jakarta, 1994.

Iriyanto. A. Baso Ence, Negara Hukum dan Hak Uji Konstitusionalitas Mabkamah Konstitusi (Telaab Terhadap Kewenangan Mabkamah Konstitusi). Alumni: Bandung, 2008.

Jimly Asshiddiqie, Pengantar Ilmu Hukum TataNegara, Rajawali Press: Jakarta, 2008.

Oostenbrink, JJ, Administratieve Sancties, Vuga Boekerij, s-Gravenhage, tt.

Khudaifah Dimyati, Pengantar Editorm, dalam: Satjipto Rahardjo, Sosiologi Hukum: Perkembangan, Metode, dan Pilihan Masalah, Universitas Muhamadiyah: Surakarta, 2002.

Patra M. Zen A, \& Daniel Hutagalung, ed, Panduan Bantuan Hukum di Indonesia, YLBHI dan PSHK : Jakarta, 2006.

Padmo Wahjono, Indonesia Negara Berdasarkan Hukum, Ghalia Indonesia, Jakarta, 1983.

Peters \& Koesriani Siswosoebroto, AG Hukum dan Perkembangan Sosial: Buku Tek Sosiologi Hukum Buku I, Pustaka Sinar Harapan: Jakarta, 199.

Peter Mahmud Marzuki, Penelitian Hukum, Prenada Kencana: Jakarta, 2005.

Philippe Nonet, Philip Selznick, Law and Society in Transition, Harper Colophon 
Books,Harper \& Row, Publishers

New York Hagerstown, San Fransisco, London, 1978.

Advokat. Gramedia Widasarana Indonesia: Jakarta, 2003.

Sudikno Mertokusumo, Mengenal Hukum Suatu Pengantar. Yogyakarta: Liberty, 1999.

Satya Arinanto, Hak Asasi Manusia dalam Transisi Politik di Indonesia. Pusat Studi Hukum Tata Negara Fakultas Hukum Universitas Indonesia. Jakarta, 2008.

Simorangkir, J.C.T. dkk, Kamus Hukum, Pen. Aksara Baru : Jakarta, 1983.

Sunaryati Hartono, Ombudsprudentie. Lembaga Negara Ombudsman: Jakarta, 2010.

Soediman Kartohadiprodjo, Pancasila Sebagai Pandangan Hidup Bangsa. Gramedia. Jakarta, 2010.

Sri Soematri, Bunga Rampai Hukum Tata Negara Indonesia, Alumni: Bandung, 1992.

Moh. Mahfud MD, Sari Kuliah Kebijakan Pembangunan Hukum Pada Program Doktor Imu Hukum PPs. FH. UII, Yogyakarta: PPs UII, 2008.

Yuda Pandu, Klien dan Penasihat Hukum Dalam Perspektif Masa Kini. Perpustakaan Nasional: Jakarta, 2001. 